\title{
Osmanlı Devleti ile İran Arasında Tabiiyet İhtilafı: Tefrik-i Tebaa Uygulaması
}

\author{
Mehmet Çetin*
}

\section{Öz}

Osmanlı Devleti ile İran yüzyıllar boyunca politik ve ekonomik bir rekabet içerisinde olmuşlardır. İki devlet arasında konar-göçer aşiretlerden, hudutların belirsizliğinden, ticari rekabetten ve mezhepsel farkl1lıklardan kaynaklanan sorunlar yaşanmıştır. $\mathrm{Bu}$ sorunlardan bir tanesi de tabiiyet sorunudur. Osmanlı Devleti, 18. yüzyılın son çeyreği ile başlayan çözülme sürecinde malî krizlerin kronik bir hal alması ve merkezi devletin etkinliğini yitirmesi nedeniyle tebaası üzerindeki denetimini kaybetmeye başlamış ve buna bağlı olarak ortaya çıkan tabiiyet sorununa karş1 19. yüzyılın ikinci çeyreği ile birlikte tefrik-i tebaa politikasını uygulama kararı almıştır. Tefrik-i tebaa uygulaması bir yandan Osmanlı topraklarında ikamet eden ve kanunlara aykırı bir biçimde dolaylı yoldan mülkiyet elde eden himayelilerin öte yandan birtakım muafiyetler elde etmek amacıyla tabiiyet değiştirenlerin sayıca giderek artması nedeniyle tahrir-i nüfus ve tahrir-i emlak gibi uygulamalarla eşzamanlı olarak yürütülmüştür. Bu çalışmanın amacı Osmanlı Devleti ile İran Devleti arasındaki tabiiyet ihtilafının çözümüne yönelik bir politika girişimini çok boyutlu bir biçimde detaylandırmaktır. $\mathrm{Bu}$ bağlamda çalışmada Osmanlı Devleti'nin kendi tebaası ile İran tebaasını ayırt etme politikası arşiv belgeleri üzerinden ve tarihsel bir perspektifle ele alınmaktadır. İran Devleti'nin tebaasının büyük bir bölümünün Müslüman olması, tabiiyet meselesini vergi, mülkiyet, miras ve askerlik gibi farklı alanlara taşımıştır. Çalışmanın bulguları tefrik-i tebaa uygulamasında mezhepsel farklılıkların ön plana çıktığını göstermektedir.

Anahtar Kelimeler: Tabiiyet, Tefrik-i Tebaa, Men-i İzdivaç, Osmanlı Devleti, İran.

Dr. Öğr. Üyesi, Dokuz Eylül Üniversitesi, İktisadi ve İdari Bilimler Fakültesi, İktisat Bölümü, mehmet.cetin@deu.edu.tr, ORCID: 0000-0002-6954-0908 


\title{
The Controversy of Subjecthood Between the Ottoman Empire and Iran: The Implementation of Discrimination of Subjects
}

\author{
Mehmet Çetin*
}

\begin{abstract}
The Ottoman Empire and Iran have been in political and economic competition for centuries. Problems arising from nomadic tribes, uncertain borders, commercial competition and sectarian differences were experienced between the two states. One of these problems was the subjecthood controversy. Starting from the second quarter of the 19th century the Ottoman Empire decided to implement the discrimination of subjects policy against the subjecthood problem, which emerged due to the weakening of the control over its subjects because of the chronic financial crisis and the loss of the central state's effectiveness during the dissolution process that stated with the last quarters of the 18th century. The implementation of the discrimination of subjects policy was carried out simultaneously with the implementation of population and property census due to the increasing number of people under protection who resided in the Ottoman territory and acquired property indirectly in violation of the law, and on the other hand, those who changed their nationality in order to obtain certain exemptions. The aim of this study is to elaborate a policy initiative aimed at resolving the subjecthood dispute between the Ottoman Empire and Iran in a multidimensional manner. In this context, the policy of Ottoman Empire to discriminate its own subjects from Persian subjects is discussed through archival documents and in a historical perspective. The fact that the state of Iran was Muslim, carried the issue of subjecthood to different areas such as inheritance, military service, taxes and property. The findings of the study show that sectarian differences stand out in the implementation of the discrimination of subjects policy.
\end{abstract}

Keywords: Subjecthood, Discrimination of Subjects, Prohibition of Marriage, The Ottoman Empire, Iran.

Asst. Prof., Dokuz Eylül University, Faculty of Economics and Administrative Sciences, Department of Economics, mehmet.cetin@deu.edu.tr, ORCID: 0000-00026954-0908 


\section{Giriş}

Tabiiyet kavramı; bir kişiyi devlete bağlayan bağı ifade etmektedir. Devletler, iç hukuka ilişkin düzenlemeler ile kendisine tabiiyet bağg ile bağl1 olanları olmayanlardan ayırarak; onlara bazı haklar vermekte ve ödevler yüklemektedir (Nomer, 2010, s. 3-4). Vatandaşlık ile tabiiyet arasındaki ayrım, devlet ile birey arasındaki bağın niteliği ve devletin egemenlik unsuru olup olmaması üzerinden belirlenmektedir (Aybay, 2006, s. 37). Egemenlik kaynağını halktan alıyor olsa da hükümdarın şahsında tecessüm ettiğinde yöneten ve yönetilen ayrımı ortaya çıkmaktadır (Beriş, 2006, s. 114-115). Osmanlı Devleti, tabiiyeti İslamî bağlamda yorumlamış ve halkı, Müslüman ve gayrimüslim olarak kategorize etmiştir (Serbestoğlu, 2011, s. 195). Müslümanlarla olan siyasi ilişkileri bakımından gayrimüslimler; Müslümanlarla savaş halinde olan ehl-i harb ve anlaşma halinde olan ehl-i ahdi kapsar. Ehl-i ahd de kendi arasında zimmi, muahid ve müste'men olarak üçe ayrılmaktadır. Bunlardan zimmi, Osmanlı Devleti'nin himayesini kabul etmiş gayrimüslimler olup, millet esasına göre örgütlenmiştir (Eryılmaz, 1990, s. 17-19). Adil bir hükümdar yönetiminde yerinde duran ve birbirine karışmayan sınıflar bütününden meydana gelen tebaa anlayışı, Osmanlı Devleti'ne Hint-İran siyasi geleneğinden geçen siyasi düşüncenin temel özelliğidir (Ocak, 1999, s. 165). Bu durum Tanzimat Dönemi'ne kadar devam etmiş; Gülhane Hattı Hümâyûnu ve Islahat Fermanı ile birlikte gayrimüslimleri de içine alan eşit bir vatandaşlık anlayışı oluşturulmaya çalışılmıştır (Dinçkol \& Işık, 2015, s. 20).

Osmanlı toplum sisteminin en önemli özelliklerinden biri, politik, sosyal ve ekonomik anlamda önemli mevkilerin aynı etnik-dil grubuna mensup olanlara ait olmadığı şeklindeki teamülün, farklılıkların birlikteliğini mümkün k1lmasıdır. Bu sayede farklı dine mensup olanlar, milletleri meydana getirerek; sistemin işlemesini sağlamışlardır (Karpat, 2006, s. 85). Millet, bir bölgenin hukuk ve himaye bahşeden bir ahitname ile İslam idaresine girmesinden doğan bir hukuki varlıktır. Bu hukuki varlık, din ve mezhep aidiyeti esasına dayanır. Osmanlı cemiyet nizamı, bu muhtelif din ve mezheplerin millet sistemi içinde varlığını sürdürmesi şeklinde oluşmuştur. Fert, doğduğu milletin içinde o cemaatin ruhani, malî ve idari otoritesine bağlı olarak yaşar (Ortaylı, 2008, s. 449-454). Bu yapı, 18. yüzyılın son çeyreği ile birlikte Osmanlı Devleti'nin yaşadığı iktisadî, siyasi ve askerî geri kalmışlıkla beraber değişmeye başlamıştır. Bu süreçte Müslümanlar 
ile gayrimüslimler arasında sosyal ve ekonomik dengeler bozulmuş; siyasi bağlılık ile etnik-dini kimlik arasında çatışmalar yaşanmaya başlamıştır (Karpat, 2006, s. 84).

Diplomatik amaçlarla Batılı ülkelere tanınan kapitülasyonların meydana getirdiği himaye sistemi, Osmanlı Devleti gücünü koruduğu müddetçe sorun yaratmazken, devletin gücünü yitirmeye başlaması ile birlikte Avrupa'nın koruyuculuğu, Osmanlı tebaası arasında cazip bir hal alarak millet sistemini çökertmeye başlamıştır (Sonyel, 1991, s. 360). Özellikle Osmanlı ile Avrupa arasındaki ekonomik ilişkilerin gelişmesi sürecinde Avrupa ile ticarete girişen Ermeni ve Rum tüccarı, bir yandan Batı Aydınlanması ile tanışmış öte yandan da cemaat yönetiminin geleneksel Osmanlı idaresi ile olan çıkar bağlarından bağımsızlaşmıştır (Somel, 2009, s. 90). Kapitülasyonlar nedeniyle rekabet edemediği Batılılar karşısında Osmanlı tebaası olan tüccar, ya tabiiyet değiştirmek ya da Osmanlı topraklarındaki konsolosların himayesine girmek zorunda kalmıştır (Eryılmaz, 1990, s. 94). Osmanlı Devleti 18. yüzy1l ile birlikte yabancı devlet himayesine ve tabiiyetine geçen böylece malî ve ticari bazı imtiyazlardan faydalanan fakat ikametgâhını Osmanlı topraklarında tutarak çeşitli suiistimallere yol açan gayrimüslim tebaasının bu faaliyetlerini engellemeye çalışmışsa da başarılı olamamıştır (Serbestoğlu, 2014, s. 64-66). Yabancı devlet konsolosları da görevlerini kötüye kullanarak; Osmanlı tebaasının tabiiyet değiştirmesini teşvik etmiştir (Eryılmaz, 1990, s. 146).

19. yüzyılda merkezi devletin tebaası ile olan bağlarının zayıflaması neticesinde tabiiyet değiştirenlerin ve himayeli sayısının hızla artması, Osmanlı tabiiyetini terk ederek; yabancı devlet tabiiyetine geçen bir kısım ahalinin Osmanlı topraklarını terk etmemesi, bir kısım Osmanlı ahalisinin ise Osmanlı Devleti'nden ayrılarak bağımsızlı̆̆ını kazanan ülkelerde kalması, işgal edilen bölgelerden Osmanlı ülkesine gerçekleşen göçler tabiiyet meselesinin hukuki bir nitelik kazanmasına yol açmıştır (Serbestoğlu, 2014, s. 67-68). Özellikle gayrimüslim tebaanın Batılı devletlerin tabiiyetine ve İran sınırındaki Ermenilerin ve Müslüman nüfusun da İran tabiiyetine yönelmesi, toprak ve nüfus kayıpları sonrasında sınır bölgelerinde ortaya çıkan nüfus ihtilafları ve kaybedilen topraklardan anavatana gerçekleşen göçler neticesinde ortaya çıkan demografik kargaşa, Osmanlı tebaası ile diğer devletler tebaasının birbirlerinden ayırt edilmesini gerektirmiştir. Yabancıların Osmanlı tebaasından olan zevce ve akrabalarına ait emlak ve/ 
veya arazi gibi bir gelir kaynağına sahip olmaları, yasak olmasına rağmen dolaylı bir biçimde emlaka tasarruf etmeleri ve buna ilişkin vergilerden kaçınmaları da tefrik-i tebaa uygulamasının bir nedenidir (BOA, A. MKT., 113/33, 27 Zilkade 1264/25 Ekim 1848). Tabiiyet kavramının, sadece yöneten ve yönetilen arasındaki ilişkileri düzenlemekten ibaret olmayıp, askerlik, vergi, mülkiyet ve miras gibi hususlarda belirleyici olması konunun önemini daha da arttırmaktadır.

Takip eden bölümde tabiiyet, tabiiyetten vatandaşlığa geçiş, tabiiyet ihtilafı gibi konuların Osmanlı Devleti özelinde ele alındığı çalışmalarla ilgili bir literatür taraması yer almaktadır. Üçüncü bölümde 19. yüzyılda İran ile Osmanlı Devleti arasındaki ihtilaflar hakkında kısa bir özet verilecektir. Bu bölüm iki devlet arasındaki diğer ihtilafların yanı sıra tabiiyet sorununa yönelik bir bağlantı bölümü niteliğindedir. Dördüncü bölümde öncelikle genel olarak Osmanlı Devleti'nde tefrik-i tebaa uygulamasının kısa bir tarihsel arka planı verilecek ardından da alt başlıklar halinde İran örneğinde tefrik-i tebaa uygulamasının esasları, süreç içerisinde belirlenen kaideler ve yürürlüğe konulan kanunname ve nizamnameler ile bunların farkl1 alanlardaki etkileri ele alınacaktır. İktisadi faaliyetler ve özellikle esnaflık, mülkiyet, miras, aile ve askerlik gibi alt başlıkların her biri kendi içerisinde derinlemesine araştırmalar yapılabilecek bir konu niteliğindedir. Konu bütünlüğ̈̈nden sapmamak adına her bir alanın tabiiyet ihtilafı ile bağlantısı üzerinden hareket edilmektedir.

\section{Genel Hatlarıla 19. Yüzyılda Osmanlı Devleti ile İran Arasındaki İhtilaf Konuları}

Osmanlı Devleti, 19. yüzyılın büyük bir kısmında İran'da 15. yüzyılın sonlarında Bozok bölgesinden Azerbaycan'a göç ederek Gence yöresini yurt edinmiş Türkmen kökenli Kaçar Hânedânı ile muhatap olmuştur (Sümer, 2001, s. 51). 19. yüzyılda Batı'nın Sanayi Devrimi'nden sonra ihtiyaç duyduğu hammadde kaynakları ve Hindistan'a giden sömürge yollarının güvenliği nedeniyle her iki devletin de emperyalistlerin hedefinde olması ve sık sık dış müdahaleye maruz kalmaları, iki devlet arasında sağlıklı bir ilişkinin kurulmasına engel olmuştur (Karadeniz, 2006, s. 37; Sarıkçığlu, 2013, s. 19). Osmanlı Devleti bünyesinde yaşayan birçok millet ve topluluğun Batılı devletlerin kışkırtmaları nedeniyle ayaklandıkları ve toplumsal 
huzursuzluklara neden oldukları bu dönemde İran'da da benzer sıkıntılar yaşanmıştır (Sümer, 2001, s. 52).

19. yüzyılın başında Fransa, Rusya'yı güneyden zorlamak ve çok cepheli bir savaşa zorlamak amaciyla hem Osmanlı Devleti'ni hem de İran'1 Rusya'ya karşı kışkırtmıştır. 1806 yılında önce Osmanlı Devleti'nin ardından da İran'ın Rusya'ya savaş açması iki devlet arasında yakınlaşmaya neden olmuştur. Takip eden dönemde iki devlet, Fransız etkisinden çıkarak İngiliz etkisine girmişlerdir. Osmanlı Devleti, müşterek düşman Ruslara karşı ortak hareket etmek amacıyla İran ile anlaşma zemini aramışsa da sonuç alamamıştır. Rusya, iki devleti birbirlerine karşı kışkırtarak kendisine karşı ittifak yapmalarını engellemiş, bunun için Sünni-Şii çatışmasını körüklemiştir (Tekdemir, 2009, s. 79-81; Sarıkçığlu, 2013, s. 22).

1820 'de sınır boylarındaki göçebeler arasında ortaya çıkan karmaşa ortamı ve İran'ın Osmanlı Devleti'nin Yunan İsyanı ile uğraşmasını firsat bilmesi nedeniyle iki devlet arasında tarihteki son savaş gerçekleşmiştir. 1823 yılında imzalanan I. Erzurum Antlaşması ile iki devlet, birbirlerinin içişlerine karışmama ve aşiret saldırılarını karşılıklı olarak engelleme konularında kararlar almıştır. Anlaşma ile göçebelerin tabiiyeti konusu da karara bağlanmıştır (Efe \& Kızı1 2017, s. 85). Anlaşmada alınan önemli bir karar da iki ülke arasında uzun süre ihtilafa neden olan karşılıklı miras meselesidir. Alınan karara göre Osmanlı topraklarında ölen İranlıların ve İran topraklarında ölen Osmanlı tebaasının vasileri olmadığı durumda beytülmale bırakılan malları, kaydedilerek saklanacak ve varisin ortaya çıkması durumunda rüsum- $u$ adiyesi ve saklandığı mahallin kirası alınarak; miras, varise teslim edilecektir. Bir sene içerisinde varis ortaya çıkmazsa miras, beytülmalden satılıp, bedeli saklanacaktır (Tekdemir, 2009, s. 86).

Osmanlı Devleti ve İran 1842 yılında yeniden savaşın eşiğine gelmiş olsa da Rusya ve İngiltere'nin savaşı önlemek amacıyla gerçekleştirdiği girişimler neticesinde 1847 yılında II. Erzurum Antlaşması imzalanmıştır. Antlaşma ile iki devlet arasındaki sınır belirlenmiş, hacıların güvenliğinin sağlanmasına, iki devletin karşılıklı olarak konsolosluk açmalarına ve ticari ihtilafların çözümlenmesine yönelik kararlar alınmıştır (Soofizadeh, 2013, s. 192-193). II. Erzurum Antlaşması'na rağmen sınır ihtilafı çözümsüz kalmış, İngiltere ve Rusya'nın çabalarına rağmen Kırım Savaşı nedeniyle anlaşmazlık devam etmiştir. İki devlet arasında özellikle Muhammere, Süleymaniye ve Zuhab sınırları konusunda bir hâkimiyet mücadelesi söz ko- 
nusu olmuştur. 1869 yılında iki devlet arasında sınır ihtilafı konusunda bir antlaşma imzalanmışsa da 1874-75'deki girişimler de sonuçsuz kalmıştır (As, 2010, s. 229-230; Sarıkçığlu, 2013, s. 21). Sınır hattının belirlenmesi, çeşitli otonom etno-kültürel grupların yaşadığı bir bölgede şekillenen tarihsel, askerî, dini, sosyo-politik, coğrafi ve çevresel faktörlerden dolayı uzun yıllar sürmüş; yerel grupların iki devlet arasında yaptığı tercihe bağl1 olarak sınırlar da değişiklik göstermiş̧ir. Bu anlamda Osmanlı - İran sınırı sıradan iki devleti birbirinden ayırmaktan ziyade ideolojik ve dini bir kırılmayı temsil etmiştir (Ateş, 2013, s. 2-12). Osmanlı yayılmacılığının aracı olan Sünni İslam ile İran'ın yayılma aracı olan resmi ideolojisi Şiilik bu sınırlarda karşı karşıya gelmiştir (Abdulla, 2008, s. 124-125).

Osmanlı Devleti ile İran arasındaki en temel sorunlardan biri de mezhepsel ihtilaflardan kaynaklanmaktadır. Osmanlı Devleti, evrensel bir Sünni Müslüman devlet olduğu iddiasıyla Sünni Müslümanlığın egemen olduğu bölgelerde meşruiyet kazanmışken; Fars monarşisi, daha ziyade Fars ulusal devleti ve dünyada Şii Müslüman devletlerin en önde geleni olmuştur (Deringil, 1990, s. 46). II. Mahmut döneminde 1826 yılında Yeniçeri Ocağı'nın lağvedilmesinin ardından Anadolu ve Rumeli'deki birçok Bektaşi tekkesi yok edilmiş, diğer tarikatlara bırakılmış yahut ıslah edilmesi amacıyla Nakşilere devredilmiştir. İran Devleti de takip eden dönemde Irak’ta Şii nüfusa karşı yoğun bir propaganda faaliyetine girişmiş; hatta İngilizlerden propaganda faaliyetleri için finansal destek sağlamıştır (Saray, 1990, s. 69). Sultan Abdülhamid Dönemi'nde İran Devleti'nin Şii ideolojisini Osmanlı toprakları üzerinde yayma girişimlerine karşı, başta çeşitli yasaklamalar olmak üzere eğitim ve öğretimin düzenlenmesi, Şii aile çocuklarının Sünni tedrisat ile yetiştirilmesi ve Şii müçtehitlerin hilafet vasıtasıyla kazanılmas1 gibi çeşitli önlemler alınmıştır (Sarıkaya, 1990, s. 420).

İran ile Osmanlı Devleti arasındaki kadim sorunların başında demografik unsurlar gelmektedir. Osmanlı Devleti’nin Batı sınırlarında yaşadığı sorunlar nedeniyle doğu vilayetlerinde merkezi otoriteyi tam olarak yerleştirememesi, sınırdaki sancakların başına atanan aşiret reislerinin keyfi eylemlerde bulunmasına, kimi zaman da Osmanlı otoritesini tanımayarak İran'a sığınmasına yol açmıştır. Konar-göçer Kürt aşiretlerinin iki devlet açısından yarattığ temel sorun, bazen İran'ın bazen de Osmanlı Devleti'nin tabiiyetine geçmek istemeleri ve sık s1k yağma hareketlerine girişmeleridir (Hakan, 2011, s. 40-45; Saray, 1990, s. 64; Sarıkçıŏlu, 2013, s. 34). 
Aşiretler ayrıca mezhep farklılı̆̆ını, daha ziyade askerden kaçmak ve vergi yükümlülüklerinden kurtulmak gibi amaçlarla suiistimal etmişlerdir. İran Devleti de kimi zaman sınırlardaki aşiretleri kendi tarafına çekerek veya kendisine sığınan aşiretleri himayesine alarak Osmanlı topraklarına saldırıda bulunmaları için teşvik etmiştir (Çağlar \& Irmak, 1973, s. 352; Sarıkçığlu, 2013, s. 40).

19. yüzyıl genelinde iki devlet arasında ihtilaf yaratan bir diğer demografik unsur da doğu sınırındaki Ermeniler ve Nasturîler olmuştur. 19. yüzyılın ikinci yarısında İran üzerinde nüfuzunu artıran İngilizler, Ermeni meselesi üzerinden iki devleti karşı karşıya getirmiştir (Karaca, 1993, s. 35). 19. yüzyılın ikinci çeyreği ile birlikte İngiltere'ye yerleşen bazı Ermenilerin lobicilik yaparak, özellikle Trabzon ve Erzurum'dan geçen İran transit ticaretinde aktif bir rol oynamaya başlamaları, Ermenilerin toplumsal itibarını büyük ölçüde artırmıştır. İngilizler de bölgesel ticaretteki paylarını artırabilmek için Ermenilere kredi desteği vermişlerdir (Süslü vd., 1995, s. 91). Özellikle Berlin Antlaşması'nın ardından Ermeniler, Osmanlı - İran sınırında çıkardıkları sorunlarla iki devlet arasındaki ilişkileri bozmaya ça1ışmış, böylece bölgeye nüfuz etmek isteyen Rusya'dan istedikleri desteği de alabilmişlerdir (Jwadeh, 1999, s. 167-169; Sarıkçığlu, 2013, s. 60). Batılı güçlerin bölgede varlık göstermeye başlaması, Ermeni hareketinin yükselişe geçişi ve İran'ın alternatif bir otorite olarak varlı̆̆ 1 , Osmanlı Devleti'ni bölgedeki tebaaya karşı daha ihtiyatlı politikalar izlemeye sevk etmiştir (Bingül, 2018, s. 510). Sonuç olarak Osmanlı Devleti ile İran arasındaki ihtilaflar; sınır sorunları, ticari meseleler, göçebe aşiretlerin neden oldukları zararlar, Ermeni meselesi ve mezhepsel anlaşmazlıklar olarak özetlenebilir.

\section{Osmanlı Devleti'nde Tefrik-i Tebaa Uygulaması}

Osmanlı Devleti'nde tefrik-i tebaa uygulamas1, 1828-29 Osmanlı - Rus Savaşı'nın ardından Yunanistan'ın bağımsızlığını kazanması üzerine gündeme gelmiştir. Uygulama Yunan tebaası olduğunu iddia edenlerin huzursuzluk çıkarmalarının önünü kesmek amacıyla Londra Protokolü çerçevesinde Osmanlı bünyesinde toplu cemaatler halinde bulunan Rum tebaas1nın tefriki ile başlamıştır (BOA, HAT., 1237/48140, 29 Zilhicce 1256/21 Şubat 1841; BOA, HAT., 1220/47757, 29 Zilhicce 1253/26 Mart 1838; 
Orhonlu, 1980, s. 5-13). Tefrik-i tebaa uygulamasına temel teşkil eden gerekçeler çerçevesinde ülkenin hemen her bölgesinde bir tabiiyet sorununun kendisini göstermesi nedeniyle ilk etapta bir nüfus sayımının yapılması ve sayım esnasında yabancı devlet himayesine girmiş olanların sayılarak; Osmanlı tebaasından tefrik edilmesi esas olarak benimsenmiştir (BOA, C. DH., 31/1521, 6 Şevval 1263/17 Eylül 1847). Fakat sayım memurlarının işin içinden çıkamaması ve yabancı devlet tebaası olanlar ile olmayanları birbirinden ayırt edememesi nedeniyle nüfus sayımı karma karışık bir hal almıştır. Bunun üzerine tefrik-i tebaa memurlarından görevlendirildikleri bölge valileriyle iş birliği yaparak; duruma netlik kazandırmaları ve pasaport kontrolü yaparak; ahalinin tabiiyet durumunu belirlemeleri istenmiştir (BOA, İ. HR., 41/1924, 22 Recep 1263/6 Temmuz 1847).

Bununla birlikte tefrik-i tebaa uygulamasının ilk döneminde yeterli ilerleme kaydedilememiş ve yaşanan gecikmelere bağlı olarak Osmanlı merkezi yönetimi, bu uygulamayı bir nizamname çerçevesinde düzenleme gereği görmüştür. Dokuz maddeden oluşan 1870 tarihli nizamname ile tefrik-i tebaa komisyonlarının teşkili kararlaştırılmış ve vazifeleri belirlenmiştir. Komisyonların Hariciye Nezareti'nin gözetiminde oluşturulması, görevlerinin nezaret tarafindan belirlenmesi, her işin sonunda gerekçeli raporların sunulması ve yabancı devletlerden de komisyona temsilciler gönderilebilmesi kararlaştırılmıştır. Vilayetlerde oluşturulacak komisyonlar ise valilerin gözetiminde teşkil edilecektir. Komisyonların gerçekleştirdikleri soruşturmalar neticesinde yabancı devlet tebaası olduğu belirlenen kişilere tüm mahkeme ve meclislerde geçerli bir şahadetname verilecektir. Tefrik-i tebaa maddesinin icrası 1869 tarihli Tabiiyet Kanunnamesi ile yakından bağlantılıdır. Osmanlı tebaası olmasına rağmen yabancı devletlerin tabiiyet ve himayesini iddia edenlerin tabiiyetleri bu kanunnameye uygun şekilde belirlenecektir (BOA, ŞD., 2391/31, 19 Zilkade 1286/20 Şubat 1870).

\section{1 İran Tebaasının Tefriki: Uygulama Esasları ve İşleyişi}

Osmanlı Devleti ile İran tebaasının tefriki, İran'ın mezhepsel farklılı̆̆ına rağmen nüfusunun büyük bir kısmının Müslüman olmas1 ve Osmanlı Devleti ile çok geniş bir sınır hattını paylaşması nedeniyle evlilik, mülkiyet, miras ve askerlik gibi alanlarda iki devlet arasında çeşitli sorunların yaşanmasına neden olmuştur. Osmanlı Devleti ile İran tebaasının 
tefriki konusu, iki devletin savaşın eşiğine geldiği 1860 y1lında gündeme gelmiştir. Çünkü iki devlet arasında çok sayıda iltica olayı da meydana gelmiştir. 1860 yılı Ocak ayında İran tebaasından ve Kürt taifesinden on beş bin hane Kars üzerinden Osmanlı Devleti'ne iltica etmiştir (BOA, C. DH., 89/4422, 28 Cemâziyelahir 1276/22 Ocak 1860, BOA, HR. SYS., 1836/6, 24 Cemâziyelahir 1276/18 Ocak 1860; BOA, HR. MKT., 323/61, 28 Cemâziyelahir 1276/22 Ocak 1860). İki devletin de görevlendirdikleri büyükelçiler, İran'dan Ferruh Han ile Osmanlı'dan Ahmed Vefik Paşa bu konu hakkında görüşmek için bir araya gelmişlerdir. İkili görüşmeler neticesinde tabiiyet sorunu hakkında sekiz maddelik bir layiha hazırlanmıştır. $\mathrm{Bu}$ layihaya göre İstanbul'da esnaflıkla uğraşan İran tebaası da diğer esnaf gibi vergilendirilecek, aslen Osmanlı tebaası iken İran tabiiyetine geçen ve aynı şekilde aslen İran tebaası iken Osmanlı tabiiyetine geçen kişiler defterlerde kayıt altına alınacak, tabiiyeti karışmış kişilerin tabiiyeti, doğum ve ikamet yerleri belirlenerek karar verilecek ve İran'dan gelen Ermeniler ya da İranlılar tabiiyetlerini meşru yollardan ispat edemezlerse Osmanl1 tebaas1 say1lacaktır (Arabkhani, 2012, s. 139).

İki devlet arasında yukarıda bahsedilen layihanın kabul edilmesine rağmen tabiiyet sorunu özellikle Irak’ta Şii nüfusun yoğun olarak yaşadığı bölgelerde artarak kendisini göstermeye devam etmiştir. Bağdat'taki İran konsolosu bölgede İranlı olduğunu iddia edenleri; aslen Osmanlı tebaası olan fakat Tabiiyet Kanunu ortaya koyulmadan önce İran tabiiyetini seçenler, aslen İran tebaası olmakla birlikte Osmanlı topraklarında yaşayanlar ve aslen İran tebaası olup ticaret yahut ziyaret amacıyla Osmanlı topraklarına gelip gidenler olmak üzere üç gruba ayırmıştır (Arabkhani, 2012, s. 138). Osmanlı Devleti de bölgedeki gelişmeleri, Bağdat Valisi tarafindan Sadaret'e yazılan yazılar ile takip etmiştir. 1860 yılı Mart ayında Bağdat Valisi, Sadaret'e yazdığı yazıda Bağdat ve civarındaki bölgelerde bulunan emlak, dükkân, hane ve arazinin büyük bir kısmının İran tebaasının eline geçtiğini, bölge halkının önemli bölümünün Şii mezhebine bağlı olması nedeniyle insanların mezhep gerekçesini ileri sürerek İran'ın tabiiyetine girmeye başladıklarını ve bu durumun bir süre daha engellenmemesi halinde bölgedeki mülklerin yarısından fazlasının İran tebaasının eline geçeceğini ifade etmiştir. Vali’ye göre İran tebaası ile Osmanlı tebaası zaman içerisinde birbirinden ayırt edilemez noktaya gelmiştir. Vali, bu nedenle uygun bir memurun tayin edilmesiyle tebaanın tefrik edilmesi ve iki devlet tebaasının kendi isteklerine göre tabiiyet değiştirmesinin önüne geçilmesi 
gerektiğini bildirmiştir (BOA, A. MKT. UM., 427/19, 12 Zilkade 1276/1 Haziran 1860).

Osmanlı Devleti, İran ile ikili ilişkilerin giderek bozulması ve tabiiyet karışıklığının ciddi bir hal alması üzerine, bu iş için Manastır Meclisi Reisi Ahmed Rasim Efendi'yi görevlendirmiş ve bundan sonra İranlılara emlak satılmamasını ve daha önce mülk sahibi olanların da ölmeleri durumunda mülklerinin Osmanlı tebaası tarafından satın aldırılması emrini vermiştir. Bunun üzerine İranlıların elinde bulunan emlak ve arazi toplanmaya başlanmış; aksi yönde eylemde bulunanlar cezalandırılmıştır. Kerbela'da bazı emlakın İran tebaasının zimmetine geçmesine müsamaha gösteren Kerbela kaymakamı görevinden azledilmiştir (BOA, A. MKT. UM., 427/19, 1 Rebiülevvel 1277/17 Eylül 1860). Bununla birlikte Devlet, bu süreçte kimsenin mağdur edilmemesine de özen göstermiştir. Bağdat'a bağl1 Fav kazasında bağc1lıkla uğraşan İranlılara, el konulan mülklerinden mahrum kalmalarının neden olacağı maddi zarar için vilayet emvalinden ödeme yapılmıştır (BOA, HR. SYS., 2929/101, 25 Rebîülevvel 1285/16 Temmuz 1868).

Ayrıca 1869 tarihli Tabiiyet Kanunnâmesi'nin yayınlanmasından önce İran tabiiyetinden çıkarak Osmanlı tabiiyetine girmek isteyenlerin İran şehbenderhânesine bilgi vererek; önceki tabiiyetleri ile bağlantılarını kesmeleri esas kaide olarak belirlenmiştir. Buna rağmen İran tabiiyetinden Osmanlı tabiiyetine geçmek isteyenler konusunda tahkikat gerçekleştiren karperdazhâne, bu talepte bulunanları vazgeçirmek yahut tabiiyet değiştirmelerini engellemek için onlara suç isnat etmek gibi usule aykırı yöntemlere başvurmuştur. İran tebaasından olanların uzun süre Osmanlı topraklarında ikamet ederek emlâke tasarruf etmeleri veya Osmanlı topraklarında doğmuş olmaları ise tabiiyet değişikliği konusunda yeterli bir delil sayılmamıştır (BOA, HR. SYS., 2931/33, 5 Zilhicce 1280/12 Mayıs 1864; BOA, HR. MKT., 665/58, 8 Recep 1286/14 Ekim 1869). Bununla birlikte kişinin tabiiyetinde ihtilafa düşülmüşse ikametinin nerede olduğu ve atalarının hangi devletin hizmetinde bulunduğu belirleyici olmuştur (Arabkhani, 2012, s. 137).

Tabiiyet Kanunnâmesi'nin yayınlanmasından sonra ise Osmanlı topraklarında ikamet eden herkesin Osmanlı tebaası muamelesi görmesi, yabancı devlet tebaasindan ise usulen bunu ispat etmesi bir kural olarak belirlenmiştir. Tabiiyetin belirlenmesi ve ortaya çıkacak duruma göre tabiiyet de- 
ğişikliği iddiasında bulunanlar hakkında gerekli muamelenin icra edilmesi, Hariciye Nezareti Kitabet Dairesi'nin vazifesine verilmiştir. Osmanlı tebaası oldukları güçlü delillerle belirlenmiş ve kayıt altına alınmış olanların tabiiyet değiştirmesi ise kanunname gereğince irâde-i seniyye verilmesine bağlanmıştır. Osmanlı hükümeti kimsenin tabiiyet işinin ertelenmesini istemediğini açıkça ifade etmiş ve gerekli olan defterlerin düzenlenmesi işi sefaretlere ait olduğundan herhangi bir gecikme yaşanır ve bu gecikmeye bağlı olarak mağduriyetler ortaya çıarsa sorumlusunun ilgili ülkenin sefareti olacağını belirtmiştir (BOA, HR. İD., 137/4, 25 Cemâziyelevvel 1291/10 Temmuz 1874).

İran tebaasının tefriki konusunda Osmanlı yönetiminin keskin kararlar almasına sebep olan diğer bir husus da başkent İstanbul ile birlikte Osmanlı Devleti'nin diğer birçok bölgesinde yaşayan demografik unsurlardan biri olan Ermeni milletinden çok sayıda kişinin İran tabiiyetine geçtiklerinin tespitidir. Bu tespitin ardından tabiiyet değişikliğinden kaynaklanan suiistimallerin engellenmesi amaciyla tefrik-i tebaa maddesinin icrası ve bunun için de bir komisyonun teşkil edilmesi kararlaştırılmıştır. Böylece birçok kişinin asıl tabiiyetine döndürülmesi amaçlanmıştır (BOA, HR. MKT., 827/64, 22 Safer 1291/10 Nisan 1874). Bununla birlikte 20. yüzyılın başlarına kadar Osmanlı ve İran tebaasının tefrikinde ve tabiiyet sorununun çözümünde kararlar, esasen şehbenderlik ve karperdazhâneler ile karşılıklı haberleşilerek; kura ve vilayet meclislerinde gerçekleştirilen tahkikatlar neticesinde verilmiştir. Nüfus ceridelerinde İranlı olduklarına dair herhangi bir işaretin bulunmadığı ve İran tebaasından olduğuna dair şahitlerin de olmadığ1 durumlarda İranlılık iddialarına itibar edilmemiştir (BOA, HR. MKT., 830/59, 11 Rebîülevvel 1291/28 Nisan 1874).

İran Devleti ise bu süreçte Şii mezhebine bağlı nüfusun belirli bir yoğunluğu aştığ yerlerde bölge halkını kendi tabiiyetine geçirme gayretinde olmuştur. Örneğin 19. yüzyılın sonunda sakinlerinin bir kısmı İran tebaası olan Necef'te Osmanlı tebaası olan halka da İranlı nâbi ve ulema vasıtasıyla İran tebaası olduklarına dair tezkereler dağıtılmıştır. Serasker Paşa tarafından Sadâret'e yazılan yazıda bölgede henüz nüfus sayımı yapılmadığından bu sorunun çaresine bir şekilde bakılmaması durumunda halkın tamamının İran tabiiyetine geçirilmiş olacağı ve İran tebaası askerlikten muaf olduğu için bu durumun da Osmanlı ordusu için sıkıntı yaratacağı bildirilmiştir (BOA, DH. MKT., 2405/105, 27 Cemâziyelevvel 1318/22 
Eylül 1900). Bunun üzerine İran tebaasının tefriki için İran tabiiyeti iddiasında bulunanların büyük bir kısmının yer aldığı Bağdat, Basra, Erzurum, Van ve Musul vilayetlerinde nüfus sayımının hızlandırılmasına ve İran ile Osmanlı Devleti arasındaki tabiiyet sorununun yeniden teşkil edilecek komisyonlar vasıtasıyla çözümlenmesine karar verilmiştir. Benzer kaygılar İran tarafında da geçerlidir. Bağdat'taki İran konsolosu tarafından Tahran'a gönderilen yazıda da Osmanlı memurlarının Kerbela'da İran tebaasından bir kısmını Osmanlı tabiiyeti altına almaya çalıştıkları bildirilmektedir. Eğer İran hükümeti tepki göstermezse birkaç yıl içerisinde İranlı tebaa tamamen Osmanlı tabiiyetine geçmiş olacağ 28/31, 23 Cemâziyelevvel 1305/6 Şubat 1888; Arabkhani, 2012, s. 140).

Osmanlı Devleti aldığı önlemleri yeni talimatnamelerle daha sıkı hale getirmeye çalışmıştır. Şöyle ki 1902 yılında Tefrik-i Tebaa Komisyonlarına verilen talimatname gereğince; (1) İstanbul'da bulunan İran tebaasının sefaretten ve taşrada bulunanların ise şehbenderler tarafindan kayıtlarının yer aldığ 1 defterler temin edilerek; kontrol edilecek ve kayıtlarda gerçekten İran tebaasından olanların pasaportları onaylanacaktır. Bu defterlerin birer kopyası Zaptiye Nezareti'ne, Şehremaneti'ne ve Hariciye Kitâbeti'ne verilecektir. Bu defterlerin dışında Osmanlı tebaasından olmasına rağmen İran tebaası olduğunu iddia edenler olursa bunların İran tabiiyeti tanınmayacaktır. (2) Komisyonlar taşrada, vilayetlerde ve livalarda İdare Meclisi üyelerinden birisi, tercüman, şehbender ve şehbenderin maiyetinde yer alan bir memur ya da tercümanın olmadığı yerlerde bölgenin muteber kişilerinden birinin katılımı ile oluşturulacaktır. Bu komisyon, tabiiyetle ilgili gerekli tahkikatı yürütecek ve düzenlediği defterleri vilayetlerde valilere ve livalarda ise mutasarrıflara teslim edecektir. Defterde kaydı olmayanların İran tebaasından oldukları iddiası kabul edilmeyecektir. (3) Osmanl1 tebaasından olmakla birlikte İran tebaası olduğunu iddia eden olursa Osmanlı Tabiiyet Nizamnâmesi'nin yayınlandığı 17 Aralık 1873 tarihinden sonra Osmanlı Devleti ile tabiiyet bağını kopararak; İran'a gidip orada 3 y1l ikamet etmemiş ve yetkili makamlar tarafından kendilerine ruhsat verilmemişse asıl tabiiyetine iade edilecektir. Bunların içerisinde halen İranlı olduğu konusunda israrcı olanlar varsa bunlara 3 ay süre verilecek ve bu süre içerisinde tüm mülkleri sattırılarak sınır dışı edileceklerdir. Bu kişiler arasından Osmanlı tabiiyetinden çıkmalarının ardından üç sene dolmadan Osmanlı topraklarına dönen olursa İran tabiiyeti yine tanınmayacaktır. (4) Tabiiyet Nizamnâmesi'nin yayınlanmasından önce İran tabiiyetine geçme- 
sine izin verilmemiş olan ve nizamnamenin neşrinden sonra İranlı olduğu iddiasını sürdüren fakat İran himayesine girmeden önce her iki devlet kanunları gereği diğer devletin tabiiyetinde olduğu kabul edilen kişiler, İran tebaasından sayılacaktır. Bununla birlikte kanunlar çerçevesinde İran tabiiyetini elde etmemiş oldukları komisyon tarafından belirlenen kişiler Osmanlı tabiiyetinde kalacaktır. (5) İran tabiiyetinde olmak isteyen ve bu nedenle Osmanlı topraklarını terk edecek kişilerden aleyhinde bir mahkeme hükmü bulunanlara İran Devleti tarafindan sağlanan himaye yok hükmünde olacaktır. Keza bu kişiler arasından hakkında mahkeme hükmü bulunanların davaları çözülmeden tabiiyet değiştirmelerine izin verilmeyecektir. Bu talimat, komisyonun işlerinde esas kabul edilecektir. $\mathrm{Bu}$ talimat komisyonun işlerinde esas kabul edilecek ve vilayet ve müstakil olarak idare edilen bölgelerde mutasarrıflara ve sefaretler tarafından karperdaz ve şehbenderlere gönderilecektir (BOA, DH. TMIK. M., 126/18, 22 Rebîülevvel 1320/29 Haziran 1902).

Ayrıca Basra'nın İran tebaasının tefriki konusundaki hassas konumu nedeniyle bu bölgede tefrik-i tebaa işini yürütecek olan komisyona üye olarak bir redif zabitinin dâhil edilmesi, 6. Ordu Müşirliği tarafından talep edilmiştir. Fakat karperdazlık talimatnamede böyle bir madde bulunmadığ 1 için bu talebe itiraz etmiştir. Basra askere alım reisliği redif binbaşıllğı ise, Basra'nın İran sınırına olan yakınlığ henüz nüfus sayımının yapılmamış olması nedeniyle bölge halkının İran Şehbenderi tarafından aldatılabileceğini ileri sürmüş ve bu sakıncaya karşı komisyonda kanunları iyi bilen, tetkikat ve tatbikat deneyimi olan bir ya da iki redif zabitinin bulundurulmasının hukuki, milli ve askerî açıdan zorunlu olduğunu ifade etmiştir. Tabiiyet meselesinin tetkikinin askeri vazifeye ihale edilemeyeceği açık olmasına rağmen Irak bölgesindeki mezhepsel hassasiyet nedeniyle komisyonda askerî kadrodan birisinin bulundurulmasına onay verilmiştir (BOA, DH. TMIK. M., 126/18, 22 Rebîülevvel 1320/29 Haziran 1902). Sonuç olarak tabiiyet sorunun ortaya çıktığı 19. yüzyılın ikinci yarısından itibaren her iki tarafın kendi hükümranlık iddiası çerçevesinde takip ettiği gerek münferit gerekse müşterek politikalar, iki toplum arasındaki geçişkenlik nedeniyle başarılı olamamış, bu durum Osmanlı Devleti özelinde sorunun teşkil edilecek komisyonlar vasıtasıyla çözülmesine yönelik bir politikanın uygulanmasına yol açmıştır. 


\subsection{Uygulama Sürecinde Alınan Kararların Esnaflık, Mülkiyet ve Miras Konularına Olan Etkileri}

Tefrik-i tebaa uygulaması esnaflık ve buna bağlı olarak vergi mükellefiyeti ile de yakından ilişkilidir. Osmanlı Devleti'nde esnaflık aslen Osmanlı tebaasına münhasır bir iktisadî faaliyettir. Bununla birlikte 1839 tarihli Balta Limanı Antlaşması ile İngiliz tüccarına iç ticarette en ziyade müsaadeye sahip olan Osmanlı tebaası gibi vergilerini ödemek kaydıyla izin verilmesi ve daha sonra benzer koşulları içeren antlaşmaların diğer devletlerle de imzalanması perakende ticareti, Osmanlı tebaasının tekelinden çıkarmıştır (Keçeci, 2017, s. 143). Osmanlı topraklarında ikamet eden İranlılar da, Osmanlı esnafinın mükellef olduğu vergileri ödemek ve esnaflık ve zanaat ile ilgili düzenlemelere tabi olmak kaydıyla Osmanlı tebaası gibi esnaflık yapabilmektedir. Buna rağmen özellikle İstanbul'da esnaflıkla uğraşan fakat ellerinde esnaf tezkiresi olmayan İran tebaasının kimi zaman tevkif edildiği dahi görülmektedir. Keza İran tebaası esnaflıkla ilgili tüm durumlarda Osmanlı mahkemelerinin kararlarına bağlı olmuş ve resmî bir görevi olmamakla birlikte Osmanlı ülkesinden geçmekte olan İranlılar, diğer yabancı devlet tebaası hakkında uygulandığı gibi pasaport, mürûr tezkeresi ve karantina nizamnâmesi uygulamalarına tabi tutulmuşlardır (BOA, İ. MSM., 3/37, 15 Rebîülahir 1260/4 Mayıs 1844; BOA, İ. MMS., 53/2372, 6 Zilkade 1292/4 Aralık 1875; BOA, HR. MKT., 244/6, 18 Zilkade 1274/30 Haziran 1858).

Tefrik-i tebaa uygulaması sürecinde esnaflık yapan bir kısım İran tebaası, özellikle askerlik yükümlülüğü olmak üzere devletten bazı konularda muafiyet talebinde bulunmuştur. Sandıklı kazasında ikamet etmekte olan İran tebaasından 20 yaşlarına ulaşanlar askere alınmak istenmişse de bunlar yabancı devlet tebaasından oldukları ve esnaflık yaptıkları gerekçesiyle istisna talebinde bulunmuşlardır. Oluşturulan komisyon ile bunların vergilerini zamanında ödeyip ödemedikleri tahkik edilmiş ve gerçekleştirilen tahkikat neticesinde (Afyon) Sandıklı' da ikamet ettiği görülen Rus tebaasından bir kişi ile İran tebaasından bir kısmının kaza dışından geldikleri, bir kısmının Sandıklı'da doğdukları, esnaflık yaptıkları ve usulen temettü vergisi vermedikçe esnaflığa kabul edilmek mümkün olmamasına rağmen bir akçe vergi ödemedikleri anlaşılmıştır. Ayrıca hepsinin aile ve hane sahibi oldukları, bölge halkı gibi davranıp bölge halkı gibi giyindikleri görülmüştür. $\mathrm{Bu}$ kişilerin durumlarının netleştirilmesi amacıyla Sandıklı'da İran şehbender 
vekilliği olmadığından (Afyon) Karahisar-1 Sahib'de bulunan İran tebaası şehbender vekili getirilerek durum soruşturulmuş; askere alınmalarının temettü vergisini ödememelerinden kaynaklandığı anlaşılmıştır (BOA, HR. MKT., 794/10, 26 Cemâziyelevvel 1290/22 Temmuz 1873).

Mülkiyet açısından ele alındığında; Klasik Dönem'de miri rejim altında devlet mülkiyetinin baskın olduğu Osmanlı Devleti'nde çeşitli istisnalarla birlikte tebaa olmayan gayrimüslimlere, arazi ve emlâk satışını diğer ülkelerle karş1ıklı olarak düzenleyen 1867 tarihli 7 Safer Kanunnamesi ve 1868 tarihli "Uyruk-1 Ecnebiyenin Emlaka Mutasarrıf Olmaları Hakkında Kanun"un ilanına kadar taşınmaz edinme hakkı tanınmamıştır. Bu noktada Osmanlı tebaası olmadığı halde Osmanlı ülkesinde mülk sahibi olmak isteyenlerin bulduğu en pratik yol, Osmanlı tebaası olan biriyle evlenmek olmuştur. Buna rağmen Osmanlı tebaası olan eşi vefat ettiğinde kocasının bağlı bulunduğu devlet kanunnâmeyi imzalamamışsa kadının mirası, yabancı devlet vatandaşı olan çocuklarına intikal ettirilmemiştir (Tanrıvermiş vd., 2013, s. 1; Yerasimos, 1976, s. 276).

Tabiiyet durumu, mülkiyet ve buna bağlı olarak miras konusunu doğrudan etkilemiştir. Nitekim Osmanlı Devleti 1869 tarihli Tabiiyet Kanunnâmesi gereğince kendi topraklarında ikamet eden herkesi kendi tebaası saymış ve ona göre muamele etmiştir. Ancak Osmanlı ülkesinde doğan yabanc1ların çocukları, doğrudan Osmanlı tebaası sayılmamıştır. Tabiiyet kanunu, yabancıların sonradan Osmanlı tabiiyetine geçişini kolaylaştırmış olsa da kapitülasyonlar nedeniyle doğum yeri esasına daha geniş bir yer ayıramamıştır. Tabiiyet Kanunnâmesi'nde Osmanlı Devleti tebaası iken yabancı devlet tebaasından biriyle evlenen Osmanlı kadınının, kocasının ölümünün ardından üç yıl içerisinde Osmanlı tabiiyetine dönebileceği öngörülmüştür. Kanunnâme'deki bu düzenleme, İslam hukukuna aykırı olduğu için özellikle mirasa ilişkin konularda hukuki karışıklıklara neden olmuştur (Fuad, 2006, s. 8-9; Topçuoğlu, 2019, s. 1821).

Nitekim uygulamada Osmanlı tebaası olan birinin mülkü yabancı devlet tebaasından olan oğluna, babasına ya da annesine intikal etmemiştir. Yabanc1 devlet tebaasindan olan birisi de Osmanlı tebaası olan birinin mülkünde hak iddia edemezdi. Osmanlı tabiiyetini terk eden birinin mülkü de Osmanlı tabiiyetinde yahut yabancı devlet tabiiyetinde bulunan evladına, babasına ya da annesine intikal etmezdi. Bu tür mülkler mahlûl sayılır ve tapu sahibi aranmadan müzayede ile satılırdı. Osmanlı ülkesinde ölen bir 
yabancının ya da yabancı ülkede ölen Osmanlı tebaasının malları asıl varislerine verilmek üzere resmî görevlilere emanet edilirdi. Osmanlı Devleti ile İran arasında da bu hükümler uygulanmıştır. Bununla birlikte İslam dünyası içerisinde dostane ilişkilerin geliştirilmesi amacıyla Osmanlı ülkesinde İranlı olup varisi olmadan ölenlerin malları, beytülmal memurları tarafindan sicile işlenerek uygun bir yerde saklanmakta, varisin yahut vekilin ortaya çıkması durumunda miras malının saklanması için ödenen kira bedeli düşülerek gerisi varise teslim edilmiştir. Bu durum, İran ile Osmanlı Devleti arasında 1823 yılında imzalanan I. Erzurum Anlaşması'nın gereği olarak uygulanmıştır. Fakat nihayetinde tabiiyet değiştirerek Osmanlı tabiiyetini seçmiş olan bir kişinin terekesi, varisleri Osmanlı tebaası değilse hazineye intikal ettirilmiştir (BOA, C. HR., 44/2177, 13 Şaban 1287/8 Kasım 1870; BOA, HR. TH., 9/36, 25 Muharrem 1317/5 Haziran 1899).

Mülkiyet ve miras konularında İran ile Osmanlı Devleti arasında sık sık ihtilaflar yaşanmıştır. Örnek vakaların birinde 1899 yılında Basra'da ölen Şeyh Nezal'in, miras olarak bıraktığ 400 bin lira değerinde emlâk, bir hayli nakit para ve mücevherin varisleri İran tebaası olduğundan hazineye intikali gerekmiştir. Varisleri mirası alabilmek için Şeyh'in aslında İran tebaasından olduğunu ispat edebilmek için yoğun çaba göstermişlerdir. Şeyh'in terekesinin önemli bölümünü teşkil eden emlâkının İ́ran sınırında olması, ihtilafı daha da arttırmıştır (BOA, Y. PRK. ASK., 151/105, $25 \mathrm{Mu}-$ harrem 1317/5 Haziran 1899).

Başka bir örnek olayda İskenderun Karperdazı Hananya'nın İzdivaç Nizamnâmesi'ne aykırı bir biçimde Osmanlı tebaasından bir kadın ile evlenmesi ve ardından vefat etmesi üzerine mirasın nasıl işlem göreceği bir anlaşmazlık konusu olmuştur. Yerel yönetimin terekeye müdahale etmesi üzerine İran Sefâreti durumu protesto etmiş ve terekenin İranlı memurlara bırakılmasını istemiştir. Tabiiyet kaleminden gönderilen yazıda ise izdivaç maddesinin Osmanlı tebaası olan kadının asıl tabiiyetini etkilemeyeceği ifade edilmiştir. Tereke konusunda gereğinin yapılması amacıyla ihtilafin çözümü İstişare Odası'na bırakılmıştır (BOA, HR. UHM., 8/12, 25 Zilhicce 1309/21 Temmuz 1892).

Muteber kişilerin tabiiyeti meselesi gündeme geldiğinde iki ülke arasında yaşanan sıkıntıların ölçüsü de büyümüştür. Bağdat'ta yaşanan bir örnek olayda Osmanlı makamları, merhum Nizam'ül-Ulema'nın oğullarını Osmanlı tabiiyetine kaydetmiş ve kendilerine tezkere vermeye çalışmış, 
bunun üzerine Bağdat'taki İran Sefâreti'nden yazılan yazı ile merhumun İran saltanat hânedânından olduğu, evliliğinin ve çocuklarının doğumunun H. 1305 (M. 1887/88) tarihindeki Men-i İzdivaç Nizamnâmesi'nden çok daha önce olduğu, hânedâna mensup birine böyle muamele edilirken diğer İranlılara nasıl muamele edildiğinin tedirginliklere yol açtığ edilerek, durumun düzeltilmesi istenmiştir (BOA, BEO., 3312/248354, 13 Rebiülahir 1326/15 Mayıs 1908). İran Bağdat Sefâreti'ne cevaben yazılan yazıda ise Osmanlı kadınlarıyla evlenen İranlılardan doğacak çocukların Osmanlı tebaası sayıldığ 1 , bunun haricinde herhangi bir muameleye gerek olmadığı ifade edilmiştir (BOA, MV., 119/74, 29 Cemâziyelevvel 1326/29 Haziran 1908).

\subsection{Uygulama Sürecinde Alınan Kararların Toplumsal ve Askerî Boyutu}

Askerî hizmetler açısından Osmanlı Devleti'nde yaşayan ve tebaa olmayan gayrimüslimler herhangi bir askerî yükümlülükleri yoktur. Bununla birlikte merkezi yönetim askerî anlamda tebaa olan gayrimüslimlerden de çok sınırlı bir biçimde istifade edilebilmiştir. Ordu, büyük ölçüde Müslüman nüfus havuzundan beslenmiştir. 19. yüzyılda Osmanlı askere alım sistemi, yurttaş askerliğine doğru bir dönüşüm geçirmiş olsa da pratikte bütün toplumu kapsayan zorunlu bir uygulamaya dönüşememiştir (Yıldız, 2009, s. 476; Çadırc1, 1985, s. 74-75). 19. yüzyılın ikinci yarısında İran sınırındaki karışıklıkları ortadan kaldırmak ve konar-göçer aşiretlerin neden olduğu sorunları bertaraf etmek amacıyla İran sınırındaki bölgelerden asker toplanmaya başlanmıştır. Hatta bu askerler arasında İran tebaasından kura yoluyla seçilmiş olanlar da bulunmaktadır. Bu durum iki devlet arasındaki anlaşmazlıkların şiddetlenmesine neden olmuştur (Karadeniz, 2006, s. 212).

Osmanlı Devleti'nin kendi tebaasını İran tebaası ile ayırt etme ve bu anlamda tefrik-i tebaa maddesinin icrası konusunda uyguladığı hem toplumsal hem de askerî anlamda en önemli ve kritik karar, Osmanlı tebaasından kadınlarla İranlı erkeklerin evlenmesinin 1874 tarihli Men-i İzdivaç Nizamnâmesi ile yasaklaması olmuştur. Bu nizamname aslında II. Mahmud döneminde yayınlanan 1822 tarihli Buyruldu'nun biçimsel olarak yeniden düzenlenmiş halidir ve Buyruldu'da yasağın çift taraflı olduğu da ifade edilmektedir (Aybay, 1980, s. 64-71; Karakoç, 2006, s. 95). 
Kern (1999)'a göre bu yasak, 400 yıllık bir geçmişe sahip olup, Osmanlı Devleti'nin İran'dan gelen ideolojik meydan okumaya verdiği bir yanıt niteliğindedir. Nitekim düzenlemenin yalnızca İran tebaasını kapsadığı, Osmanlıların diğer ecnebiler ile evlenmelerinin Osmanlı kanunlarına uygun olduğu görülmektedir (BOA, HR. TO., 367/87, 25 Recep 1301/21 Mayıs 1884; Kern, 1999, s. 140-147).

Sorunun mezhepsel niteliği gereği önceleri bu yasak sadece her iki devletin Müslüman tebaasını kapsamış ve gayrimüslim İran tebaasının gayrimüslim Osmanlı kadınlarıyla evlenmelerine ve bu evlilikten doğacak çocukların İran tebaasından sayılmasına izin verilmiştir. Buna rağmen yasak, zamanla gayrimüslim tebaayı kapsayacak şekilde genişletilmiştir (BOA, DH. MKT., 2068/112, 20 Cemâziyelevvel 1312/19 Kasım 1894). Nizamnâmenin birinci maddesinde yer alan "Osmanlı tebaası ile İran tebaasının izdivacı katiyen yasaktır" ifadesi bunu açıç̧a belirtmektedir. Bu yasak ile amaçlanan mezhepsel bölünmelerin önünü kesmektir. Ayrıca Osmanlı topraklarında yerleşik İranlıların sayıca hızla çoğalması da bu kararın alınmasında etkili olmuştur. Dolayısıyla Osmanlı ülkesindeki Şii nüfusun artmasının engellenmesi amaçlanmaktadır. Kanuna aykııı biçimde bir evlilik gerçekleşecek olursa bu evlilikten doğan erkek çocuklar, nizamnâmenin üçüncü maddesi gereğince Osmanlı topraklarında ikamet ettikleri sürece Osmanlı tebaası sayılacak ve her türlü askere alma ve bedelât-1 askeriye gibi mirî yükümlülüklere tabi olacaklardır. Evlenmelerinin ardından Osmanlı tebaası olarak kalan kadınların ölmeleri durumunda üzerlerinde bulunan emlâk ve arazi yine Osmanlı ülkesinin malı sayılacak ve evlatlarına miras bırakılabilecektir (BOA, DH. MKT., 2894/78 22 Şaban 1327/8 Eylül 1909; BOA, HR. HMŞ. İŞO., 224/15, 14 Recep 1325/23 Ağustos 1907).

Yabancılarla evlenen Osmanlı kadınlarının yabancı devlet tebaası sayılması kadim bir uygulama olduğundan bundan doğacak çocukların askerlik kurasına katılması da nizama aykırı görülmüştür. Fakat İran tebaasından olup Osmanlı kadınlarıyla evlenenlerin çocuklarına istisna tanınması durumunda; Osmanlı topraklarında evlenerek yerli hükmüne giren ve Osmanlı topraklarında doğan çocukları Osmanlı ordusunda görev alan birçok İranlı bulunduğu için çok sayıda asker kaybedilmiş olacaktır. Ayrıca birçok kişi de İran tabiiyeti iddiasında bulunacaktır. Bu da devlet açısından birçok sakıncayı beraberinde getirecektir (BOA, HR. MKT., 796/99, 18 Cemâziyelahir 1290/13 Ağustos 1873). Men-i İzdivaç Nizamnâmesi buna 
bir istisna teşkil etmektedir. Kanuna aykırı olarak gerçekleşen bir evliliğin ardından aile üyeleri, Osmanlı ülkesini terk eder ise İranlı gibi muamele görecektir. Keza bu gibi evliliklerde Osmanlı tebaası olan taraf, eşinin tabiiyetini benimserse erkek çocukları da askerlik hizmetine alınmayacaktır. Konsolosluklarda kavas ya da tercüman gibi hizmetlerde bulunanların ise 1890 y1lı Şubat ayından itibaren askerlik hizmeti ile yükümlü tutulmas1na karar verilmiştir (BOA, HR. HMŞ. İşO., 183/43, 4 Cemâziyelevvel 1313/23 Ekim 1895).

İran Sefâreti, Osmanlı kadınlarının İran tebaası ile evliliklerini yasaklayan nizamnâmeye, bu evliliklerden doğan çocukların zorla askerî hizmete alındığı iddiasıyla itiraz etmiştir. Osmanlı hükümetine göre bu itiraza rıza gösterilmesi durumunda Osmanlı tebaası olan kadınlar evlatlarını askerlikle ilişkili yükümlülüklerden kurtarmak için İranlılarla evlenmeye teşvik edilmiş olacaktır (BOA, MV., 1/19, 18 Rebîülahir 1302/4 Şubat 1885). Hariciye Nezâreti, Osmanlı Devleti ile İran arasında imzalanan sözleşmenin altıncı maddesinde yer alan İran tebaasının Osmanlı ülkesinde askerlik hizmeti vermekle yükümlü olmadığı ifadesinin yasağa rağmen izdivaç eden Osmanlı kadınlardan doğan çocukların babalarına binaen İranlı tanınması hakkındaki iddiaları için yeterli bir delil olmadığını ilan etmiştir. Osmanlı Devleti özel bir kanun ile Osmanlı kadınlarının İranlılarla izdivacını yasaklamış ve yasağa aykırı biçimde gerçekleşecek evliliklerden doğan çocukların askeri hizmetle yükümlü tutulacağını ilan etmiştir. Osmanlı hükümeti bu durumun Osmanlı Devleti'nin kendi menfaatine göre düzenlediği bir kanun hükmünden kaynaklandığını, misliyle mukabele etme ilkesi gereğince İranlı kadınlarla izdivaç eden Osmanlı tebaası çocuklarının dahi İran' da askere alınmasının İran hükümetinin muhtariyetinde olduğunu belirtmiştir (BOA, A. MKT. MHM., 492/58, 20 Safer 1304/18 Kasım 1886).

İran Sefâreti bu açıklama karşısında protestosunu tekrarlamış ve evlilik yasağının Men-i İzdivaç Nizamnamesi'nin neşrinden önce var olmadığını ve nizamnamenin birinci maddesinde yer alan "Kemâ fi-s-sâbık" ifadesinin uygun olmadığını belirtmiştir. Buna rağmen Hariciye Nezareti yasağın öteden beri geçerli olduğunu ve Men-i İzdivaç Nizamnamesi ile daimi k1lındığını belirtmiştir (BOA, A. MKT. MHM., 492/58, 20 Safer 1304/18 Kasım 1886; BOA. MV., 15/18, 25 Rebiülevvel 1304/22 Aralık 1886). Tabiiyet Kanunu'nun 13. maddesi uyarınca aile reisine verilen tezkirenin tüm aile üyelerini kapsıyor olması nedeniyle İran hükümeti yasağa yeniden 
itiraz etmiş fakat Osmanlı Devleti, yasağın mezhep ihtilafına dayandığı gerekçesiyle itirazı yeniden reddetmiştir. İzdivaç yasağ 1 Osmanlı Devleti'nin yıkılmasının ardından bir süre daha yürürlükte kalmış ve 1926 yılında kaldırılmıştır (Serbestoğlu, 2012, s. 217; Aybay, 1980, s. 71).

Osmanlı ile İran tebaasının tefrikine askerî boyutu açısından bakıldığında İran tebaası olduğu sahih olanlardan asker talep edilmemiştir (BOA. HR. MKT., 665/58, 8 Recep 1286/14 Ekim 1869). Osmanlı ülkesinde ikamet eden İran tebaası, ecnebi sıfatında bulunacağı için diğer yabancı devlet tebaası gibi bedelât-1 askeriye gibi Osmanlı tebaasına özgü olan yükümlülüklerden müstesna tutulmuştur (BOA, İ. MMS., 53/2372, 6 Zilkade 1292/4 Aralık 1875). Osmanlı tebaası olan kadınlarla evlenen ecnebilerden olan erkek çocuklar ise Osmanlı tebaası sayıldığından kura usulünce askere alınmıştır (BOA, HR. MKT., 708/13, 19 Zilhicce 1287/12 Mart 1871). İran tebaasıyla evlenen Osmanlı kadınlarından olan erkek çocukların askerî hizmetle yükümlü oldukları, Ahz-1 Asker Kanunnâmesi'nin 32. maddesinde ifade edilmiştir. Fakat İran Sefâreti'nin itirazı ve yoğun müzakere süreci neticesinde 20 Temmuz 1909 tarihli Dâr-1 Şûra-yı Askerî kararı ile yasağa rağmen İran tebaası ile evlenen Osmanlı kadınlarının erkek çocuklarından 25 Ekim 1886 tarihli Ahz-1 Asker Nizamnâmesi'nin neşrinden önce doğanların askerlik hizmetinden istisna tutulması, bu tarihten sonra doğanların ise askerî hizmetle yükümlü olması kararlaştırılmıştır (BOA, DH. MKT., 1616/34, 14 Şaban 1306/15 Nisan 1889; BOA, DH. MKT., 313/33, 3 Cemâziyelahir 1312/2 Aralık 1894; BOA, DH. MKT., 2894/78, 22 Şaban 1327/8 Eylül 1909).

Osmanlı Tabiiyet Nizamnâmesi'nin altıncı maddesinde yabancı bir devletin ordusunda hizmete girenlerin tabiiyetinin düşürülmesinin devletin inisiyatifinde olduğu ifade edilmiştir. Bu nedenle devlet, İran'a giderek orada yalnızca askerlik hizmetine girenlerden bazılarının Osmanlı tabiiyetinin düşürülmesini ve daha sonra bunların Osmanlı ülkesine geri dönmelerini bir tür gözü açıklık olarak nitelendirmiştir. Osmanlı tebaasından ve özellikle Bağdat ve Basra halkından bir kısmı, askerlik hizmetinden kurtulmak amaciyla İran'da Buşehr'e giderek; İran ordusunun hizmetine girmiş, daha sonra ise Osmanlı Devleti'ne göç etmiştir. Bu nedenle İran tabiiyeti iddiasında bulunanların büyük bir kısmının yer aldığı Bağdat, Basra, Erzurum, Van ve Musul vilayetlerinde nüfus sayımının hızlandırılmasına karar verilmiştir. Keza Basra Vilayeti'nde ve Amara Sancağı'nda Osmanlı 
tebaasından olan bazı kişiler, askerlik hizmetinden kurtulmak amacıyla İran şehbenderhânesine başvurarak himaye talep etmişlerdir. Benzer girişimler Cezayir Bahr-i Sefid'de de büyük ölçüde gerçekleşmiştir. Birçok vatan evladının yabancı devlet tabiiyetini kabul etmesinin ülkeye vereceği zarar düşünülerek gerekli tedbirlerin Dâhiliye Nezareti tarafindan alınmas1 ve Buşehr Şehbenderi'nin de vatani görevlerini yerine getirmeleri için kaçaklara çağrı yapması ve memleketlerine iade edilmeleri konusunda girişimlerde bulunması kararlaştırılmıştır. Osmanlı Devleti özellikle servet sahibi kişilerden bu şekilde askerlik hizmetinden kaçanların dikkatle takip edilmesine özen göstermiş, bu kişilerin Osmanlı tabiiyetinden çıkarılmayarak; askerlik hizmetiyle her zaman mükellef tutulmalarına karar vermiştir (BOA, DH. İD., 61/2, 13 Şevval 1328/18 Ekim 1910; BOA, BEO., 3229/242134, 9 Zilhicce 1325/13 Ocak 1908).

Keza İran tabiiyetinden Osmanlı tabiiyetine geçen ve bunun üzerine askerlik yükümlülügünden ve bazı diğer vergilerden muafiyet talep edenler de olmuştur. İran tebaası iken Osmanlı tabiiyetini kabul eden ve İzmir'de ikamet eden Mehmet Hasan, Osmanlı tabiiyetini kabul etmesinin üzerinden üç sene geçtiğini ifade ederek; askerlik yükümlülügünden ve diğer vergilerden yedi sene muaf tutulmasının gerekliliğine dair bir arzuhal vermiştir. Benzer örneklerin yaşanması durumunda nasıl bir uygulamanın geçerli olacağına dair Şûra-yı Devlet, Meclis-i Vükelâ ve Harbiye Nezâreti arasında gerçekleştirilen yazışmalar neticesinde askerlik hizmetinin tüm Osmanlı tebaasını kapsadığı bir zamanda gerçekleşen tabiiyet değişikliğinin istisnaya açık olmadığı, Osmanlı tabiiyetinin kabulü ile birlikte Osmanlı kanun ve düzenlemelerinin tüm vazife ve yükümlülükleri ile birlikte geçerli olacağı ifade edilmiştir. Bu gibilerin daha önce tabi oldukları devlet kanununca icap edecek askerlik hizmetinin tabiiyet değişikliği esnasında hangi aşamasında ise Osmanlı ordusunda da o aşamaya denk gelen bir hizmeti ifaya mecbur oldukları, önceden askerlik hizmetinin zorunlu olmadığ bir ülkenin tabiiyetinde iseler yaşıtları Osmanlı tebaasıyla aynı derecede askerî hizmet ve mükellefiyete tabi olmaları kararlaştırılmıştır (BOA. DH. MUİ., 96/1, 8 Cemâziyelevvel 1328/18 Mayıs 1910).

Tabiiyet üzerinden belirlenen askerlik yükümlülüğü, Osmanlı tebaası olan ve/veya sonradan Osmanlı tabiiyetini seçen farklı milletlerce birçok suiistimale konu olmuştur. Örneğin aslen İran tebaasından olan ve sonradan Osmanlı tabiiyetine geçen Museviler, askerlik yükümlülügünden muafiyet 
talep etmişlerdir. Bunların muafiyet talebi reddedilmiş; Osmanlı tabiiyetine kabul edilmeleri fakat diğer Osmanlı tebaası gibi bedelât-1 askeriye ödemekle yükümlü tutulmaları uygun görülmüştür (A, DH. TMIKK. M., 123/34, 24 Muharrem 1320/3 Mayıs 1902). Bir başka suiistimal de zamanında İran'dan gelerek; Osmanlı Devleti'nin başta Bağdat ve Basra olmak üzere farklı bölgelerine yerleşen, zamanla yerli hükmüne geçip; mahallî nüfusa kaydolunan, Osmanlı kadınlarıyla evlenip; Osmanlı tebaası gibi askerlik hizmetini yerine getiren ve bu şekilde Osmanlı tebaası gibi tanınan İranlılar tarafindan gerçekleştirilmiştir. Bunlar evlatlarını askerlik hizmetinden ve çeşitli miri yükümlülüklerden kurtarmak amacıyla İranlı olduklarını iddia etmeye başlamışlar, bölgelerinde bulunan İran şehbenderinin de desteğini alarak; idare meclisleri ve komisyonlar vasitasıyla yapılan tetkikat neticesinde yeterli delile sahip olanları, İranlı oldukları kanaatiyle ecnebi sıfatı almışlardır. Bu gibilerin nüfustan kaydı silindiği gibi askerlik hizmetinde bulunanlar da ihraç edilmiştir (BOA, DH. MKT., 2015/87, 5 Rebîülahir 1310/27 Ekim 1892).

\section{Sonuç}

Osmanlı Devleti'nin 18. yüzyılın sonundan itibaren iktisadî ve askerî aç1lardan Batılı güçlerin gerisinde kalması, devlet ile tebaası arasındaki bağların zayıflamasını da beraberinde getirmiştir. Bu süreçte önceki dönemde Batılı ülkelere tanınan kapitülasyonlar vasıtasıyla önce ecnebi tüccar, Osmanlı tebaasına göre daha avantajlı bir toplumsal konuma yükselmiş, daha sonra da yabancı konsoloslar vasıtasıyla gayrimüslim Osmanlı tebaası, giderek artan ölçülerde Batılı ülkelerin himayesine ve tabiiyetine girmeye başlamıştır. Batılı ülkeler ikili ticaret antlaşmaları, askerî ve politik baskı ve misyonerlik yoluyla bu nüfuzu giderek daha arttırmışlardır. Bu süreçte yabancı devlet tebaası olan fakat Osmanlı ülkesinde elde ettiği avantajlı konumu kaybetmek istemeyen ahali de Osmanlı topraklarında ikamet etmeye devam etmiş ve Osmanlı tebaası olan akrabaları vasıtasıyla emlak, arazi vb. gelir kaynaklarına dolaylı olarak tasarruf etmeye başlamıştır. Osmanlı Devleti, bu koşullar altında ortaya çıkan politik, malî ve askerî sakıncaları bertaraf edebilmek, tabiiyet sorunlarını çözebilmek ve tebaasının haklarını koruyabilmek amacıyla tefrik-i tebaa uygulamasını başlatmıştır.

Osmanlı Devleti ile İran arasındaki tabiiyet ihtilafının ortaya çıkışı 19. yüzyılın ikinci yarısına rastlamıştır. İki devlet arasındaki ihtilafların özün- 
de önceki dönemlerden süre gelen sınır anlaşmazlıkları, sınırda yerleşik aşiretlerin sık sık yer ve tabiiyet değiştirerek yağma faaliyetlerine girişmesi, iki devletin birbirlerinin tüccarına karşı engelleyici faaliyetleri, İran Devleti'nin Ermenileri Osmanlı aleyhine kullanması ve en önemlisi de iki devletin İslam dininin Şiilik ve Sünnilik gibi birbirine zıt iki ekolünün temsilcisi olarak izledikleri ideolojik politikalar yer almaktadır. İki devletin de Müslüman olması, tefrik-i tebaa uygulaması çerçevesinde atılan her adımın askerlik, mülkiyet ve miras gibi toplumsal alanın farklı boyutlarını etkilemesine neden olmuştur.

İki devlet tebaasının birbirinden ayırt edilmesi gerekliliğinin temelinde mezhepsel sıkıntılar yatmaktadır. Osmanlı Devleti, bu konuda uygulad1ğ1 politikalar ile kendi topraklarındaki Şii etkisini azaltmayı amaçlamıştır. Hem Bağdat ve civarındaki bölgelerde daha yoğun olmakla birlikte emlak, dükkân, hane ve arazinin İran tebaasının eline geçmeye başlaması hem de bölge ahalisinin mezhepsel gerekçelerle İran tabiiyetine temayül etmesi Osmanlı Devleti açısından tefrik-i tebaa uygulamasını bir mecburiyet haline getirmiştir. Osmanlı Devleti, İranlılara emlak satılmaması, İranlıların ellerindeki mülklerin toplatılması, tabiiyet değiştirenlerin Osmanlı tabiiyetine döndürülmesi gibi politikaların yanı sıra 1869 yılında ilan ettiği Tabiiyet Kanunnamesi ve 1874 tarihli Men-i İzdivaç Nizamnamesi ile tabiiyet değiştirmek isteyenlere yönelik kaideler belirlemiş ve kendi tebaasından olan kadınların İranlılarla evlenmesini yasaklamıştır. Bu kaideler, miras uygulamaları ve askere alım konularında önemli karışıklıkları da beraberinde getirmiştir.

Sonuç olarak bakıldığında tefrik-i tebaa uygulaması kadim geçmişleri olan iki devlet özelinde karşılıklı meydan okumanın farklı bir boyutunu oluşturmuştur. Osmanlı Devleti açısından bu uygulamanın zorunluluğu çok daha karmaşık ve farklı nedenlere dayanmaktadır. Bu açıdan uygulama, dağılmakta olan bir imparatorluğun tebaası ile olan bağlarını muhafaza edebilmek amacıyla tabiiyetten vatandaşlı̆ga geçişte bir ara aşamayı teşkil etmektedir. Fakat 19. yüzyılda her iki devlet de Batılı güçlerin yoğun nüfuzu karşısında ve mezhepsel ideolojileri sebebiyle tabiiyet ve tabiiyetten kaynaklanan iktisadî faaliyet, mülkiyet, miras, evlilik ve askerlik gibi konularda kati çözümler üretememiştir. Benzer sorunların Osmanlı Devleti'nin yıkılmasından sonra da Türkiye, İran ve Irak arasında devam ediyor oluşu, uzun vadeli sorunların çözümünde tarafların müşterek bir irade ortaya koyamadıklarını açıkça göstermektedir. 


\section{Beyan}

$\mathrm{Bu}$ makale etik kurul kararından muaftır. Çalışmada katılımcı bulunmamaktadır. Çalışma için herhangi bir kurum veya projeden mali destek alınmamıştır. Çalışmada kişiler ve kurumlar arası çıkar çatışması bulunmamaktadır. Telif hakkına sebep olacak bir materyal kullanılmamıştır.

\section{Disclosure}

The article is exempt from the Ethics Committe Decision. There are no participants. The author received no financial support from any institution and there's no conflict of interest. No material subject to copyright is included. 


\section{Kaynakça}

Abdulla, N. (2008). Imparatorluk, sınır ve aşiret. AvestaYayınları.

Arabkhani, R. (2012). Sultan II. Abdülhamit dönemi Osmanl1-İran ilişkilerinde atabat-ı aliyat [Yayımlanmamış doktora tezi]. Gazi Üniversitesi Sosyal Bilimler Enstitüsü.

As, E. (2010). XVI yüzyıldan cumhuriyetin ilk yıllarına kadar Türk ve İran sınır sorunları ve çözümü. Atatürk Yolu Dergisi, 12(46), 219-253. https://doi.org/10.1501/Tite_0000000325

Ateş, S. (2013). The Ottoman - Iranian borderlands - making a boundary, 1843-1914. Cambridge University Press.

Aybay, R. (1980). Kadının uyrukluğu üzerinde evlenmenin etkisi. Ankara Üniversitesi Siyasal Bilgiler Fakültesi Yayınları.

Aybay, R. (2006). Vatandaşlık hukuku. İstanbul Bilgi Üniversitesi Yayınlar1.

Babıali Evrak Odası Evrakı (BEO) 3229/242134, 3312/248354.

Beriş, H. E. (2006). Küreselleşme çağında egemenlik-ulusal egemenliğin yeni sinırlart. Lotus Yayınları.

Bihterin, V. D. \& Işık, A. (2015). 1924 anayasası döneminde yurttaşlık anlayışı. Marmara Üniversitesi Hukuk Fakültesi Hukuk Araştırmaları Dergisi, 21(1), 13-43.

Bingül, Ş. (2018). XIX. yüzyılın ikinci yarısında Van [Yayımlanmamış doktora tezi]. Ankara Üniversitesi Sosyal Bilimler Enstitüsü.

Cevdet Dâhiliye (C. DH.) 31/1521, 89/4422.

Cevdet Hâriciye (C. HR.) 44/2177.

Çadırc1, M. (1985). Osmanlı İmparatorluğu'nda askere almanda kura usulüne geçilmesi 1846 tarihli askerlik kanunu. Askeri Tarih Bülteni, (18), 59-75.

Çağlar, B. K. \& Irmak, S. (1973). Cevdet Paşa tarihinden seçmeler II. Milli Eğitim Bakanlığı Yayınları.

Çetin, M. (2020). Tabiiyetten vatandaşlığa: Yunan tebaası örneğinde Osmanlı Devleti'nde tefrik-i tebaa uygulaması. International Journal of 
History Studies, 12(5), 2599-2620. https://10.9737/hist.2020.933

Dâhiliye Nezâreti İdare Evrakı (DH. İD.) 61/2.

Dâhiliye Nezâreti Mektubî Kalemi (DH. MKT.) 313/33, 1616/34, 2015/87, 2068/112, 2405/105, 2894/78.

Dâhiliye Nezâreti Muhaberat-1 Umumiye İdaresi Evrak1 (DH. MUI.) 96/1.

Dâhiliye Nezâreti Tesri-i Muâmelât ve Islahat Komisyonu (DH. TMIK. M.) $123 / 34,126 / 18$.

Deringil, S. (1990). The struggle against shiism in Hamidian Iraq. Die Welt des Islams, 1(4), 45-62.

Efe, H. \& Kızıl, M. (2017). Sınır kavramı ve tarihsel süreç içinde Türkiyeİran sınırının oluşumu ve önemi. Erzincan Üniversitesi Sosyal Bilimler Enstitüsü Dergisi, X(I), 77-90.

Erdem, F. H. (2012). Yeni anayasa doğru: vatandaşl1k, Osmanl1-Türkiye anayasalarında ve yeni anayasada vatandaşlık. SETA Analiz, (51), 4-24.

Eryılmaz, B. (1990). Osmanlı Devleti’nde gayrimüslim tebaanın yönetimi. Risale Yayınları.

Hakan, S. (2011). Osmanlı arşiv belgelerinde Kürtler ve Kürt direnişleri. Doz Yayınları.

Hâriciye Nezâreti Hukuk Müşavirliği İstişare Odası Evrak1 (HR. HMŞ. İŞO.) 183/43, 224/15.

Hâriciye Nezareti İdare (HR. İD.) 137/4.

Hâriciye Nezareti Mektubi Kalemi Evrak1 (HR. MKT.) 244/6, 323/61, 665/58, 708/13, 794/10, 796/99, 827/64, 830/59.

Hâriciye Nezâreti Siyasi (HR. SYS.) 1836/6, 2929/101, 2931/33.

Hâriciye Nezâreti Tahrirat Kalemi Evrakı (HR. TH.) 9/36.

Hâriciye Nezâreti Tercüme Odası Evrak1 (HR. TO.) 367/87.

Hâriciye Nezâreti Umur-1 Hukuk-1 Muhtalita Müdüriyeti (HR. UHM.) $8 / 12$.

Hatt-1 Hümâyun (HAT.) 1220/47757, 1237/48140.

İrade Hâriciye (İ. HR.) 41/1924. 
İrade Meclis-i Mahsus (İ. MMS.) 53/2372.

İrade Mesâil-i Mühimme (İ. MSM.) 3/37.

Jwaideh, W. (1999). Kürt milliyetçiliğinin tarihi kökenleri ve gelişimi. İletişim Yayınları.

Karaca, A. (1993). Anadolu slahâtı ve Ahmet Şâkir Paşa (1838-1899). Eren Yayınları.

Karadeniz, Y. (2006). İran'da sömürgecilik mücadelesi ve Kaçar Hanedanı, 1795 - 1925. Bakış Yayınları.

Karakoç, S. (2006). Külliyâtt-ı kavânîn. (Haz. M. A. Aydın vd.). Türk Tarih Kurumu Yayınları.

Karpat, K. (2006). Osmanlı'da değişim, modernleşme ve uluslaşma. İmge Kitabevi.

Keçeci, S. (2017). Osmanlı Devleti'nde ecnebilerin esnaflı̆̆1 meselesi (1838-1861). International Journal of History Studies, 9(3), 141-166. https://10.9737/hist.2017.546

Kern, K. M. (1999). The prohibition of Sunni-Shi'i marriages in the Ottoman Empire: s study of Ideologies [Yayımlanmamıs doktora tezi]. Columbia Üniversitesi.

Mahmud F. (2006). Tabiiyyet. (Haz. C. Osmanoğlu). Derin Yayınları.

Meclis-i Vükela Mazbataları (MV.) 1/19, 28/31, 119/74.

Nomer, E. (2010). Türk vatandaşlık hukuku. Filiz Kitabevi.

Ocak, A. Y. (1999). Din ve düşünce hayatı. İçinde E. İhsanoğlu (Ed.). Osmanlı Devleti ve Medeniyeti Tarihi. (s.159-193). IRCICA.

Orhonlu, C. (1980). Yunanistan'ın Osmanlı Devleti’ne karşı takip ettiği siyaset (1866-1885). Türk Dünyası Araştırmaları Dergisi, 1(6), 5-13.

Ortaylı, İ. (2008). Türkiye teşkilat ve idare tarihi. Cedit Neşriyat.

Polat, E. G. (2011). Osmanlı'dan günümüze vatandaşlık anlayışı. Ankara Barosu Dergisi, (3), 127-157.

Sadâret Mektubî Kalemi Evrakı (A. MKT.) 113/33.

Sadâret Mektubî Kalemi Umum Vilayât Evrakı (A. MKT. UM.) 427/19. 
Sadâret Mektubî Mühimme Kalemi Evrakı (A. MKT. MHM.) 492/58.

Saray, M. (1990). Türk-İran münasebetlerinde Şiiliğin rolü. Türk Kültürünü Araştırma Enstitüsü Yayınları.

Sarıkaya, M. S. (1990). Dini ve siyasi bakımdan Osmanl1-İran münasebetleri. Türk Kültürü, XXXI(363), 406-422.

Sarıkçığlu, M. (2013). Osmanlı - Iran hudut sorunları (1847-1913). Türk Tarih Kurumu Yayınları.

Serbestoğlu, İ. (2011). Zorunlu bir modernleşme örneği olarak Osmanlı tabiiyet kanunu. OTAM, Journal of The Center for Ottoman Studies, 29(29), 193-214. https://doi.org/10.1501/OTAM_0000000572

Serbestoğlu, İ. (2012). Öteki perspektifiyle Osmanlı kadınının İranlılarla evlenme yasağı. Uluslararası Sosyal Araştırmalar Dergisi, 5(20), 213220 .

Serbestoğlu, İ. (2013). Balkan savaşları ve tabiiyet sorunu. Tarih İncelemeleri Dergisi, XXVIII(2), 471-486.

Serbestoğlu, İ. (2014). Osmanlı kimdir? Osmanlı Devleti'nde tabiiyet sorипи. Yeditepe Kitabevi.

Somel, S. A. (2009). Osmanlı reform çağında Osmanlıcılık düşüncesi (1839-1913). İçinde M. Gültekingil \& T. Bora (Eds.), Modern Türkiye'de Siyasi Düşünce Cilt 1 (s. 88-98). İletişim Yayınları.

Sonyel, S. (1991). Osmanlı İmparatorluğu'nda koruma (protégé) sistemi ve kötüye kullanılışı. Belleten, $L V(213), 169-188$.

Soofizadeh, A. (2013). I. ve II. Erzurum Antlaşmalarının siyasi açıdan değerlendirilmesi. Tarih Araştırmaları Dergisi, 32(54), 183-194. https:// doi.org/10.1501/Tarar_0000000559

Sümer, F. (2001). Kaçarlar. TDV İslam Ansiklopedisi, XXIV, Türkiye Diyanet Vakf1 Yayınları, 51-53.

Süslü, A., Kırzıoğlu, F. \& Yin, R. (1995). Türk tarihinde Ermeniler. Kafkas Üniversitesi Yayınları.

Şûrâ-y1 Devlet Evrak1 (ŞD.) 2391/31. 
Tanrıvermiş, H., Doğan, V. \& Akipek, Ş. Ö. (2013). Türkiye'de tarihsel gelişim süreci içinde yabancıların taşınmaz edinimlerinin analizi: TÜBİTAK-KAMAG 110G020.

Tekdemir, A. (2009). XIX. yüzyılın ilk çeyreğinde Osmanl1-İran ihtilafları ve 1821-1823 savaşı. Karadeniz Uluslararası Bilimsel Dergi, (4), 7795.

Topçuoğlu, A. A. (2019). İslam hukukunda ve 1869 tarihli Tabiiyet-i Osmaniye Kanunnamesi'nde çocukların vatandaşlık durumu. Uluslararası Sosyal Araştırmalar Dergisi 12(62), 1816-1831. https:// DOI:10.17719/jisr.2019.3189

Yerasimos, S. (1976). Azgelişmişlik sürecinde Türkiye 2. Gözlem Yayınları.

Y1ldız Perakende Evrak1 Askeri Maruzat (Y. PRK. ASK.) 151/105.

Yıldız, G. (2006). Neferin adı yok (Zorunlu askerliğe geçiş sürecinde Osmanlı Devleti'nde siyaset, ordu ve toplum, 1826 - 1839). Kitabevi Yayınları.

Yurt, V. (2019). Osmanlı Devleti'nde 19. yüzyllın ikinci yarısında evliliğe tahdit tedbirleri: Iranlılarla evlilik yasă̆ [Yayımlanmamış yüksek lisans tezi]. İstanbul Üniversitesi Sosyal Bilimler Enstitüsü. 